\title{
Mediações entre a fidalguia portuguesa e o Marquês de Pombal: o exemplo da Casa de Lavradio
}

Fabiano Vilaça dos Santos ${ }^{1}$

Doutorando-USP

\section{RESUMO}

Este artigo aborda as relações entre o Marquês de Pombal e a fidalguia portuguesa, tomando como exemplo a Casa representada pelo $2^{\circ}$ marquês do Lavradio. A análise privilegia uma perspectiva de mediação, em lugar do conflito, contrapondo-se à vertente mais tradicional da historiografia que enfatiza os atritos entre Pombal e a nobreza de linhagem.

Palavras-chave: Marquês de Pombal; Mediação; Fidalguia.

\section{ABSTRACT}

This article deals with the relationship between the Marquis of Pombal and the Portuguese nobility, taking as an example the House represented by the second Marquis of Lavradio. The analysis favors a perspective of mediation rather than conflict, thus opposing the most traditional view of historiography which emphasizes the misunderstanding between the Marquis of Pombal and the highborn nobility.

Keywords: Marquis of Pombal; Mediation; Nobility.

Os estudos sobre a dinâmica administrativa do Império colonial português têm destacado, recentemente, a temática das trajetórias administrativas de agentes destinados ao governo das conquistas ultramarinas. ${ }^{2}$ Algumas abordagens tratam dos conflitos que envolveram os representantes da Coroa, governadores-gerais, vice-reis ou governadores de capitania e as demais instâncias da administração colonial, ou mesmo da relação entre os ditos representantes da autoridade real no ultramar e os seus interlocutores em Lisboa.

São igualmente importantes para a configuração das trajetórias administrativas os estudos sobre os recrutamentos dos agentes, que observam as suas origens sociais, sendo a condição mais ou menos nobre um critério que se verifica na hierarquização dos cargos da governança ultramarina. Um fator importante a ser considerado no recrutamento dos indivíduos era a experiência militar, ou aquela adquirida anteriormente no desempenho de outras 
funções de governo. De forma geral, as relações familiares, os serviços prestados embutidos na linhagem e as redes de alianças políticas estavam presentes na escolha dos indivíduos, uma vez que a função governativa representava uma fonte valiosa de benefícios consignados sob a forma de mercês. ${ }^{3}$

O presente artigo procura analisar a relação da Casa de Lavradio com alguns pares na Corte, em um período de mudanças políticas empreendidas pelo Secretário de Estado Sebastião José de Carvalho e Melo, marquês de Pombal, dirigidas à fidalguia portuguesa. São abordados os mecanismos pelos quais a Casa representada pelo $2^{\circ}$ marquês do Lavradio firmou a sua posição na típica sociedade portuguesa de Antigo Regime, visando à manutenção de seu prestígio e honradez, tendo o marquês de Pombal como um "aliado/adversário" a ser considerado.

\section{HistÓRIA FAMILIAR do 2o MARQUÊS DO LAVRADIO}

D. Luís de Almeida Portugal Soares Alarcão Eça e Melo Silva e Mascarenhas, da varonia dos Almeidas, $5^{\circ}$ conde de Avintes e $2^{\circ}$ marquês do Lavradio, nasceu a 26 de junho de 1729 na Quinta da Conceição, situada no reguengo da Ribaldeira, em Lisboa, pertencente ao morgado instituído em 1475 por um antepassado remoto, o conde Rui Gomes de Alvarenga. Foi batizado em julho do mesmo ano pelos avós paternos, o $3^{\circ}$ conde de Avintes, D. Luís de Almeida, e a condessa D. Joana Antônia de Lima. Aos dez ou doze anos, há controvérsias, assentou praça no Regimento de Infantaria de Elvas, tendo sido armado cavaleiro em 1746 por iniciativa de seu tio materno, o duque de Aveiro, que seria acusado de participar da tentativa de assassinato de D. José I, em 1758.

A formação preliminar do $2^{\circ}$ marquês do Lavradio foi orientada pelo tio-avô, o cardeal D. Tomás de Almeida, primeiro Patriarca de Lisboa, que entregou a educação do sobrinho aos cuidados de um abade francês, cujo nome foi omitido na biografia de Lavradio. Curiosamente, a presença do referido abade em Portugal deveu-se a uma indicação de D. Luís da Cunha, célebre por sua experiência política e cultural no estrangeiro. Filho do $2^{\circ}$ conde de Avintes, D. Tomás de Almeida ocupou os cargos de bispo do Porto e de Lamego e de desembargador da Casa da Suplicação. Foi o bispo quem realizou, na Sé de Elvas, o casamento de D. José I com D. Mariana de Áustria. ${ }^{4}$

Por iniciativa do pai, D. Luís de Almeida Portugal seguiu para Madri, em 1749, e depois para Paris, a fim de completar seus estudos, de cuja natureza, 
lamentavelmente, não há informações precisas. Sabe-se que em Paris estudou as artes militares, com possíveis noções de fortificação, pois entrou em contato com M. de Valeré, engenheiro-militar que esteve em Portugal e executou as obras dos fortes de La Lippe e da Graça, em Elvas, recebendo em remuneração dos serviços a patente de tenente-general e o cargo de conselheiro da guerra. Sobre a passagem por Madri, as informações são ainda mais vagas, tendo o biógrafo registrado apenas que a estada do herdeiro da Casa de Avintes fora facilitada pelos parentes de sua avó materna, D. Teresa de Moscoso Osório, condessa e, depois de viúva, marquesa de Santa Cruz, filha do $9^{\circ}$ conde de Monteagudo e 5ํㅜ marquês de Almazán, da nobreza espanhola. Em 1761, D. Luís de Almeida alcançou o posto de coronel-comandante do Regimento de Cascais, no qual chegou a Brigadeiro em recompensa pela atuação na Campanha Peninsular de 1762, episódio da Guerra dos Sete Anos. ${ }^{5}$

A titulação da Casa de Avintes está relacionada ao contexto da consolidação da dinastia de Bragança; esta promoveu muitos nobres à titulação pela fidelidade empenhada em favor da nova Casa reinante. $O$ título de $1^{\circ}$ conde de Avintes foi concedido em 1664, a D. Luís de Almeida, que foi mestre-decampo de Infantaria, governador das Armas das Províncias do Algarve e do Rio de Janeiro (entre 1652 e 1658), e último administrador português da praça de Tânger, na África. Esta, depois de 1640, passou a ser administrada por vários Grandes da nobreza, ${ }^{6}$ e em 1662 fez parte do dote da infanta D. Catarina, dada em casamento ao rei Carlos II, aliado dos Bragança. O $2^{\circ}$ conde de Avintes, D. Antônio de Almeida, lutou na famosa Batalha do Ameixial, na Guerra da Restauração, foi governador das Armas da Província de Trás-osMontes, em 1705, durante a Guerra de Sucessão de Espanha, e membro do Conselho de Estado e do Conselho da Guerra. Casou-se com D. Maria Antônia de Bourbon, filha do $3^{\circ}$ conde dos Arcos, e dessa união nasceram D. Tomás de Almeida e D. Lourenço de Almeida; este último serviu na Índia e foi governador de Pernambuco e de Minas Gerais. ${ }^{7}$

O título de $1^{\circ}$ marquês do Lavradio foi dado a D. Antônio de Almeida Soares Portugal, $4^{\circ}$ conde de Avintes, em remuneração pelos serviços prestados no governo de Angola, de 1749 a 1753. Em 1760 foi nomeado vice-rei do Estado do Brasil, falecendo poucos meses após ter assumido o cargo. O $2^{\underline{0}}$ marquês do Lavradio casou-se em 1752 com D. Mariana Teresa Rita de Távora, filha do $5^{\circ}$ conde de São Vicente, aparentado dos marqueses de Távora, acusados da tentativa de regicídio de D. José I.

De acordo com a concepção linhagista que regulava o ethos da nobreza, a participação dos titulares das Casas nobiliárquicas no Real Serviço não de- 
pendia apenas de suas experiências pessoais. Estas eram importantes para respaldar a indicação para determinada comissão, mas os préstimos dos antepassados, considerando-se a posição dos cargos que ocuparam na hierarquia administrativa ou militar; os feitos em momentos mais ou menos delicados da conjuntura política de Portugal; o exercício do governo colonial ou das províncias militares do Reino; missões diplomáticas e outras possibilidades de serviço formavam uma espécie de patrimônio simbólico da linhagem, utilizado pela geração que ostentava a titulação e estava na posse dos bens da Casa. Possuir uma folha de relevantes serviços prestados à monarquia era um fator de prestígio embutido na linhagem, pois os préstimos serviam para impulsionar a carreira das sucessivas gerações. ${ }^{8}$

Nesse sentido, pode-se dizer que o cardeal D. Tomás de Almeida, filho secundogênito de $\mathrm{D}$. Antônio de Almeida, $2^{\underline{o}}$ conde de Avintes, cumpriu a missão de engrandecer sua Casa, que não se restringia ao primogênito. Os serviços do primeiro Patriarca de Lisboa foram "doados" após sua morte ao sobrinho, o $4^{\circ}$ conde de Avintes, contribuindo para que sua Casa fosse elevada ao marquesado de Lavradio. ${ }^{9}$ O governo de uma província militar tal como foi exercido pelo $2^{\circ}$ conde de Avintes, em Trás-os-Montes, no delicado episódio da Guerra da Sucessão de Espanha, exemplifica o momento em que, segundo Nuno Gonçalo Monteiro, a "elite restrita da grande nobreza" monopolizava os postos mais altos e os comandos militares em Portugal. ${ }^{10}$

A folha de serviços do $2^{\circ}$ conde de Avintes não se limitou aos postos militares. Ocupou cargos em duas importantes instâncias da administração central do Reino: o Conselho de Estado e o Conselho da Guerra. O primeiro foi criado em 1562 como órgão consultivo do Rei, que o presidia. Com o surgimento das Secretarias de Estado, a partir de 1736, o Conselho teve suas funções reduzidas até que parou de se reunir. O Conselho da Guerra, criado logo após a Restauração, ainda em 1640, tinha o objetivo de zelar pela gestão e conservação do aparato militar, a organização de tropas e o julgamento de questões militares. ${ }^{11}$

A "trajetória" do $4^{\circ}$ conde de Avintes e $1^{\circ}$ marquês do Lavradio, pai do representante da Casa tratado particularmente neste artigo, é reveladora de conexões importantes na circulação de um nobre no Real Serviço. Antes de vir para o Brasil na qualidade de vice-rei, o $4^{\circ}$ conde de Avintes havia passado pelo governo de Angola, o que reforça a interpretação de que havia uma ligação entre o desempenho desse cargo e a indicação para vice-rei do Estado do Brasil, proposta por Maria de Fátima Silva Gouvêa. ${ }^{12}$ Angola era exceção entre as praças africanas no que concerne à seletividade dos seus governado- 
res, e some-se a isso o fato comumente aceito pela historiografia de que o governo do Brasil cresceu em prestígio e importância no século XVIII, em contraposição ao da Índia, que não tinha mais o mesmo peso na balança dos interesses portugueses, como nos dois séculos anteriores. ${ }^{13}$

Segundo Nuno Gonçalo Monteiro, o governo colonial era uma das principais "vocações" da fidalguia e os territórios que tinham maior valor simbólico, pela rentabilidade auferida à Coroa portuguesa, eram destinados aos Grandes. ${ }^{14}$ Exemplos de governos de reconhecida projeção eram os de Pernambuco e Minas Gerais, estes ocupados no início do século XVIII por D. Lourenço de Almeida, tio-avô do $2^{\circ}$ marquês do Lavradio, além do Rio de Janeiro e da Bahia. Esta capitania e a de Pernambuco eram importantes centros produtores de açúcar e de tabaco, ativas no tráfico de escravos e no circuito comercial atlântico. Minas Gerais vivia na primeira metade do século XVIII os áureos tempos da mineração, e o Rio de Janeiro consolidou-se ao longo do século como porto de escoamento da produção mineira e, mais tarde, como centro político-administrativo do Império português na América. No fim do governo de D. Lourenço de Almeida, foram descobertas oficialmente as primeiras minas de diamantes.

Os sucessivos deslocamentos verificados na "trajetória" da Casa de Avintes/Lavradio, considerando-se o respectivo valor das posições ocupadas pelos antepassados do $2^{\circ}$ marquês do Lavradio no Real Serviço, permitem compreender como o representante da Casa aqui privilegiado, acrescido de suas experiências pessoais, estava credenciado para exercer os postos para os quais foi designado. As indicações para cargos administrativos ou militares, de acordo com sua ordem de grandeza, não estavam dissociadas de necessárias conexões e mediações políticas. Considerá-las na folha de serviços dos antepassados do $2^{\circ}$ marquês do Lavradio seria estender demasiadamente este tópico. Basta que se tenha a noção de que os serviços dos familiares condicionaram a "trajetória" daquele que foi nomeado governador e capitão-general da Bahia, em 1768, e vice-rei do Estado do Brasil no ano seguinte, cargo que ocupou até 1779 .

A indicação de Lavradio para o cargo de governador da Bahia é polêmica. Segundo seu biógrafo e descendente direto, o $6^{\circ}$ marquês do Lavradio, D. José I, ao pensar na execução de uma série de diretrizes para a educação de seu neto, o príncipe D. José, cogitou escolher o marquês do Lavradio para ser seu preceptor. O conde de Oeiras, movido por ciúme, teria demovido o rei dessa idéia, sugerindo que o marquês fosse enviado ao governo da Bahia. ${ }^{15}$ Porém, as relações familiares e o prestígio na Corte teriam beneficiado decisi- 
vamente a administração do marquês do Lavradio, desde a sua nomeação para o governo da Bahia. A aprovação das ações do governador e vice-rei na colônia partiu, na caracterização de Dauril Alden, da conjunção de dois fatores essenciais: por um lado, as qualidades de um bom governante a serviço da Coroa, quais fossem a prudência, o valor, a responsabilidade na prestação de contas e a experiência na guerra; por outro lado, as boas relações na Corte garantidas pelo status familiar. ${ }^{16}$ Em diversas ocasiões, Lavradio sondou seus interlocutores para saber que tipo de conceito havia na Corte sobre o seu desempenho, ponto que será retomado mais adiante.

A apresentação dos dados biográficos do marquês do Lavradio está respaldada no conceito que Pierre Bourdieu concebe como a "trajetória" de um indivíduo ou personalidade, delineada com base em seu nome e em seus espaços de formação: no caso de um nobre de linhagem, a titulação da Casa, as conexões familiares e as características de seu preparo, militar em especial, e intelectual. A "trajetória" se completa com o cruzamento dos atributos pessoais com a "obra" realizada pelo mesmo indivíduo ou personalidade, tornado "agente eficiente" em um contexto histórico determinado, qual seja, o da formulação e aplicação de novas diretrizes para a revitalização do Império português no período pombalino. ${ }^{17}$ Dessa forma, pode-se entender como a origem familiar e a experiência militar encaixavam o marquês do Lavradio no modelo do administrador colonial.

\section{O NOBRE NA SOCIEDADE DE ANTIGO REGIME: BREVES PALAVRAS}

A origem bem demarcada e evocada como princípio de legitimidade, enriquecida pelos feitos militares e serviços prestados à monarquia pelos membros de uma linhagem, definia a base da condição aristocrática. O bom nascimento implicava a assimilação de certos valores inerentes à condição de nobre: guerra, honra, ação, coragem, força; virtudes corporificadas em atitudes e até modos de vestir, indicativos do sentimento e da consciência de pertencer à nobreza.

Nuno Gonçalo Monteiro fala de um ethos ou habitus da aristocracia de Corte em Portugal, no período compreendido entre o último quartel do século XVII e o início do século XIX. ${ }^{18}$ Esse ethos ou habitus representaria um "sistema de disposições incorporadas", acumuladas e passadas pelas gerações, amparadas por dois suportes fundamentais: a idéia de Casa e a de Serviço ao Rei.

Em relação à Península Ibérica, segundo Nuno Gonçalo Monteiro, ou- 
tros autores têm acentuado a perspectiva de uma "lógica distributiva" ou do benefício, como Antônio Manuel Hespanha que analisa o poder altamente estruturador das alianças, caracterizadas pela prestação de serviços e pelo recebimento das respectivas recompensas. ${ }^{19}$ Essa "lógica distributiva" estava associada ao caráter corporativo da sociedade portuguesa, uma vez que havia uma espécie de convicção, por parte da fidalguia, de um dever do Rei em conceder mercês aos nobres a seu serviço. ${ }^{20}$

Pelo pertencimento a uma família cuja tradição de serviços era constantemente evocada, a fidalguia requeria as mercês reiterando constantemente a fidelidade à monarquia. Para Sérgio Cunha Soares, esta era, antes de tudo, uma função política da nobreza, ou seja, assumir no presente, pela via da memória, o papel de exemplo, enumerando feitos e virtudes da linhagem. Além de uma função, no entanto, a nobreza tinha também uma finalidade política sustentada por três pilares essenciais: a "defesa” do reino, o "amparo" da monarquia e a "quietação" da República. ${ }^{21}$ Imbuída dessas noções e prerrogativas, a nobreza de linhagem justificava a sua posição de principal apoio político da monarquia.

\section{O MARQUÊS DE Pombal, A FIDALGUIA E O MARQUÊS DO LAVRADIO}

A historiografia sempre se mostrou bastante afeita à idéia de que Pombal pretendia consolidar-se no ministério - o que realmente se verificou diminuindo ou anulando a influência de grupos identificados como concorrentes. ${ }^{22} \mathrm{~A}$ antiga nobreza de Portugal e a Companhia de Jesus constituíramse nos dois principais obstáculos à consolidação do ministério pombalino, tendo sido a última suprimida de Portugal e de seus domínios, medida seguida pela França e pela Espanha. Na interpretação mais corrente nos textos sobre o período de 1750 a 1777, o marquês de Pombal transformou-se no verdadeiro algoz da fidalguia: maculou sua honra, desprezou seus serviços, escarneceu de seus privilégios concedidos e assegurados pelos sucessivos ocupantes do trono português. Em resumo, desacreditou a linhagem e a lógica do prestígio, vilipendiando a identidade do nobre amparada no pressuposto da antigüidade. Não se pretende negar a validade dessa interpretação, o que não quer dizer que deva ser aceita como algo inquestionável ou definitivamente concluído.

Os textos sobre o período pombalino produzidos nos últimos cem anos têm algumas matrizes importantes, como a obra de João Lúcio de Azevedo, 
que privilegiou no início do século XX a atuação extremamente incisiva e centralizadora de Pombal. As interpretações posteriores são tributárias, em boa parte, do esquema de sua obra, que apostou no caráter personalista e despótico do ministro na condução dos assuntos políticos e administrativos ${ }^{23}$

Outra obra sobre o marquês de Pombal, menos referenciada que a de João Lúcio de Azevedo, embora enfatize o mesmo caráter personalista do ministério pombalino, é a de Francisco José da Rocha Martins. A diferença é que Rocha Martins concentrou-se nos últimos anos de vida de Pombal, desde a sua demissão em 1777 até a sua morte em 1782, e nas críticas à sua atuação. Entre as acusações dirigidas a Pombal

também lhe imputavam outro crime: o de ter oferecido aos espanhóis a cabeça do marquês de Lavradio, vice-rei do Brasil, a troco da paz nas regiões americanas ... Constituía, porém, louco desígnio, refinada calúnia, apontá-lo como sacrificador daquele fidalgo em câmbio da trégua. Ruim e vil boato era aquele, tremenda impostura; e desejava que o conde de São Paio, seu genro, mostrasse à esposa do vice-rei a carta em cujas páginas protestava contra o aleive ... O marquês de Lavradio, D. Luiz de Almeida Portugal e Mascarenhas, era sobrinho do duque de Aveiro por sua mãe, dona Francisca das Chagas Mascarenhas ... A esposa, dona Maria Rita de Távora, era filha do conde de São Vicente, ligado à família supliciada ${ }^{24}$

O suposto afastamento do marquês do Lavradio da Corte, ou a tentativa de Pombal de sacrificá-lo em nome da paz com os castelhanos nos domínios meridionais da América, acusação incluída no rol de detratações ao Secretário de Estado após a sua demissão, tem relação com o que João Lúcio de Azevedo mencionou sobre o casamento de D. Maria com o infante D. Pedro. O Secretário acusava D. Pedro de inepto e excessivamente influenciado pelos fidalgos da Corte, tendo se esforçado ao máximo para retardar o casamento da herdeira do trono com o infante seu tio. ${ }^{25} \mathrm{Na}$ ótica do afastamento da Corte dos setores concorrentes, cuja influência seria nefasta à sua projeção política, o conde de Oeiras teria, então, motivos para impedir que Lavradio assumisse a função de preceptor do fruto da união que teria tentado embaraçar.

Por sua vez, os embates da linha de ação de Sebastião de Carvalho e Melo com a fidalguia, que teriam resultado no afastamento da Corte do marquês do Lavradio, devem ser relativizados. Se o marquês foi preterido como preceptor do príncipe D. José pelo ciúme do conde de Oeiras, e indicado para o governo da Bahia, seu tio D. Tomás de Almeida foi o primeiro diretor de es- 
tudos secundários, de 1759 a $1771 .{ }^{26} \mathrm{O}$ cargo tinha prestígio, pois fazia parte da reforma do sistema educacional idealizada por Sebastião de Carvalho e Melo. Soma-se a esses fatos a afirmação de Kenneth Maxwell de que a administração pombalina foi partilhada com "pequenos nobres e aristocratas ilustrados como o Morgado de Mateus e o Marquês do Lavradio". ${ }^{27}$

Estudo criterioso é o clássico de Francisco José Calazans Falcon, que contempla o ministério pombalino na variedade de aspectos relativos ao reformismo ilustrado. ${ }^{28} \mathrm{O}$ autor analisa as matrizes teóricas do reformismo, as prerrogativas absolutistas embutidas nas realizações do marquês de Pombal, e a ótica mercantilista que orientou a política portuguesa no século XVIII com o objetivo de modernizar as estruturas políticas, econômicas e sociais de Portugal.

Com relação à fidalguia, Francisco Falcon chama a atenção para a existência de grupos refratários às reformas pombalinas, o que motivou os atritos com o marquês de Pombal. Esse grupo de fidalgos representantes de antigas Casas era identificado como o dos "puritanos", muito ligados à Inquisição, um dos alvos da política de secularização intentada por Pombal. No que se refere em particular aos assuntos da Casa de Lavradio, o combate ao "puritanismo" estava no centro das preocupações do $2^{\circ}$ marquês do Lavradio, pois os casamentos de suas duas primeiras filhas foram acertados com indivíduos tidos como "puritanos". Isso reforça a necessidade de uma mediação entre Pombal e setores da antiga nobreza não identificados como oponentes diretos. ${ }^{29}$

As críticas a Pombal foram freqüentes logo após a sua saída do ministério, em 1777. Em alguns casos, utilizou-se a estrutura representativa da sociedade de Antigo Regime para direcionar com mais exatidão os desmandos pombalinos. Elaboraram-se, também, peças literárias com o intuito de denunciar os males da monarquia portuguesa creditados a Pombal, como o soneto a seguir, que desfere um ataque ao ministro justamente pela postura adotada em relação à fidalguia:

Dize cruel Marquês que Lucro tiras;

Do ódio, que tiveste à Fidalguia;

Não temeste, que pudesse vir um dia;

Que mostrasse teus embustes, e mentiras;

Se então tu infeliz bem refletiras;

No dano que por ti se lhe seguia;

Vivera a Corte em paz, e alegria;

E o que hoje em tu vês, talvez não viras; 
Desprezaste cruel, e intentastes,

Usando mil cavalas, mil intrigas,

Apartado do Trono, que enganastes:

O Lucro que tiveste não o digas,

Que essas vis gentes que exaltastes

Contra ti se conspiram inimigas. ${ }^{30}$

Algumas críticas dirigidas a Pombal trazem reflexões subjacentes sobre a manutenção do ethos do nobre de Corte e da estrutura da sociedade portuguesa. Acompanhando os sonetos detratores da atuação de Pombal, algumas décimas ensaiaram a linha de pensamento e a crítica dos desmandos pombalinos. Uma delas, transcrita em seguida, obedece ao próprio modelo tripartido da sociedade de Antigo Regime, associando, a cada um dos seus estados componentes, um desmando praticado por Pombal. O texto anônimo atribui ao primeiro estado, o Clero, queixas contra Pombal pela usurpação das jurisdições e dos direitos eclesiásticos. Ao terceiro estado, representado pelo Povo, Pombal teria causado um sério dano de ordem política: contrariou as máximas do zelo e da boa ordem, asseguradas pelo soberano em relação aos seus súditos, pondo em risco os negócios públicos em nome da satisfação de seus interesses privados e dos indivíduos a quem protegia.

O segundo estado, identificado com a Fidalguia, evidentemente o que mais importa destacar aqui, teria sofrido ação não menos violenta sobre suas prerrogativas. É oportuno sinalizar para o fato de que o autor do texto utilizou o termo "fidalguia" para designar a nobreza de linhagem, em oposição à nobreza de serviços: ${ }^{31}$

Os Fidalgos se queixam que sendo fiéis servos de Seu Senhor, amando-o, respeitando-o, obedecendo-o e servindo-o, com amor e afeição ... este mau homem soube afastar aqueles que podiam dar conselhos, aqueles que podiam descobrir suas intrigas, e os funestos fins delas ... As pessoas de virtude, ciência, prudência e humanidade, a uns desterrou para a companhia das feras; a outros meteu em masmorras ... a outros constituiu réus de Lesa Majestade ... buscando para executores da sua vontade e tirania, homens idiotas, Ministros sem Letras, mais amigos da fortuna do mundo do que da virtude ... Manchou a sua memória, as suas famílias, as suas Casas com o odioso labéu de traidores, sendo fiéis servos ... embaraçando os seus requerimentos, tratando-os como homens, cujos ascendentes não fossem o ornato do estado, sendo os que sempre defenderam a Coroa, a cus- 
ta do seu sangue, por amor, e por obrigação ... Impediu suas alianças: Não as atendeu; desprezou-os ... As mercês que o Soberano benignamente distribuía ao merecimento, ele as ocultava, e confundia, de sorte que não chegavam a ter efeito, nem a aparecerem... ${ }^{32}$

Mesmo não se identificando, esse "observador" devia estar situado em um patamar privilegiado que lhe permitiu, posto que com parcialidade, detectar os pontos nevrálgicos atingidos pela política pombalina. O soneto e os trechos da décima fazem parte de um conjunto de escritos anônimos detratores de Pombal, que sintetizam as discussões realizadas até o presente. Falam dos ataques aos privilégios tradicionais da fidalguia; da intervenção nas alianças familiares; da relação serviço/remuneração, na qual o monarca estava diretamente envolvido. Os escritos também tecem críticas ao grupo de apaniguados enobrecidos por iniciativa de Pombal, uma nobreza de serviços que teria se voltado contra ele.

Os escritos contrários ao marquês de Pombal surgiram após a sua demissão, graças ao medo da perseguição que o Secretário de Estado poderia empreender contra os adversários, como apontou Francisco Falcon. Manifestaram-se, nessa ocasião, "inimigos reais ou fictícios" repletos de sentimentos de vingança, que se valeram de denúncias sobre a conduta pessoal e administrativa de Pombal, exatamente como ilustram os fragmentos aqui apresentados. ${ }^{33}$ Pelo teor das palavras e a escolha dos alvos, é provável que o autor fosse elemento da velha nobreza, preterido na indicação para algum cargo ou ofendido pela perseguição à sua Casa. De modo geral, a historiografia do período pombalino, quer enfatize o despotismo ministerial ou o caráter ilustrado das reformas pombalinas, cristalizou a perseguição do Secretário do Reino à fidalguia a partir de um caso emblemático: o suplício dos marqueses de Távora e do duque de Aveiro e o desterro do resto da parentela acusada da tentativa de regicídio de D. José I.

\section{MARQUÊS DE POMBAL: UM ANTEPARO INEVITÁVEL}

É preciso visualizar alguns códigos relacionais que revestem de nobreza o ato de governar, mantendo estreitas ligações com o universo político da Corte. Segundo Antônio Manuel Hespanha e Ângela Barreto Xavier, o universo normativo do Antigo Regime tinha contornos complexos. Os comportamentos sociais possuíam, na concepção do "governo de si mesmo", uma correspondência entre as virtudes interiores e o comportamento exterior. Esse uni- 
verso mental e as práticas sociais decorrentes estavam atrelados a modos prescritos de continência do gesto e a atitudes em prol do interesse público. ${ }^{34}$ As normatizações da sociedade de Antigo Regime passavam, inexoravelmente, pela constituição de alianças, relações que determinavam a posição mais ou menos favorável dos indivíduos na cena política.

Essas relações eram muitas vezes assimétricas, representadas por "amizades" desiguais, eminentemente hierarquizadas e geradoras de constantes estados de equilíbrio e desequilíbrio nas manifestações de poder e nas estratégias de ganhos políticos. Isso se explica pela existência de um “pólo credor”, disponível para conceder benefícios ou retribuições por serviços prestados, e um "pólo devedor" ciente de suas obrigações de respeito, serviço e atenção. ${ }^{35} \mathrm{O}$ fiel da balança era a honra de quem estava diretamente envolvido nesse mecanismo de reciprocidades e alianças. O Rei era o principal "pólo credor", e Pombal acabou desempenhando o papel de anteparo entre a alta nobreza e a pessoa do monarca.

Na estrutura político-administrativa portuguesa do século XVIII, devese destacar a centralidade da Secretaria de Estado dos Negócios Interiores do Reino. ${ }^{36}$ Desempenhava papel relevante no sistema de informação e controle das instâncias de governo, recebendo as consultas feitas ao Rei, chancelandoas e enviando-as para os órgãos competentes. Sua jurisdição era ampla, incluindo a competência para tratar de assuntos eclesiásticos, do Paço e da Casa Real. Por essas prerrogativas, a Secretaria de Estado dos Negócios do Reino, como também era conhecida, acabava funcionando como suporte das decisões régias, propondo medidas legislativas e executivas. Dessa forma, tornase mais fácil entender por que o marquês de Pombal, à frente dessa repartição de 1756 a 1777, teve a oportunidade de realçar a sua participação nos negócios de Estado e em assuntos de foro privado, tais como os enlaces matrimoniais. O próprio combate ao "puritanismo" representou uma justificativa de intervenção.

No período pombalino ocorreram mudanças na legislação matrimonial que incidiram sobre práticas habituais da nobreza. A lei de 17 de agosto de 1761 codificou a regulação dos casamentos segundo a concepção pombalina, coibindo os contratos onerosos para as famílias nobres, remodelando a organização das cerimônias e das recepções, a dimensão dos enxovais, o valor dos dotes, o tempo dos festejos e a quantidade de padrinhos, entre outras medidas que, no entender de Pombal, arruinavam as Casas e constituíam prática abolida em outras Cortes européias. ${ }^{37}$ 


\section{FORMAÇÃO DE ALIANÇAS: OS CASAMENTOS DA CASA DE LAVRADIO}

Os casamentos na Casa de Lavradio retratam como essa família teve que lidar com as reviravoltas do jogo político na conformação de seus laços de parentesco e alianças. A primeira filha do marquês do Lavradio, D. Teresa Francisca de Almeida, casou-se em janeiro de 1768 com D. José Xavier de Noronha Camões de Albuquerque de Sousa Moniz, $5^{\circ}$ conde de Vila Verde e $4^{\circ}$ marquês de Angeja, tenente-general, conselheiro de Estado e governador das Armas da Corte ${ }^{38}$ Salientando a conveniência desse consórcio, embora o $3^{\text {o }}$ marquês de Angeja fosse apontado como "puritano", assim se expressou Lavradio:

Meu primo, meu amigo, e meu senhor, a V.Ex. ํㅡão será novo o quanto sempre me foi estimável a aliança com a casa de V.Ex. ${ }^{\text {, }}$, e vindo consegui-la agora tão gostosamente em tempo em que eu me achava de posse da amizade, e favor de V.Ex. ${ }^{\underline{a}}$... Espero minha filha saiba agradecer, e merecer a escolha que V.Ex. ${ }^{\underline{a}}$ fez dela ... Ao meu estimável novo filho escrevo, e se ele antes destas novas alianças me devia já a amizade de que ele não pode deixar de lembrar-se ... ele tem no meu coração igual parte, que aquela que a natureza lhe deu no de V.Ex...$^{39}$

O casamento de outra filha mostra como Pombal se fez presente na construção das alianças entre Grandes Casas fidalgas. D. Maria Rosa de Almeida se casou com o primogênito de Manuel Teles da Silva, $6^{\circ}$ conde de Vilar Maior, $6^{\circ}$ conde de Tarouca e $2^{\underline{0}}$ marquês de Penalva, apontado como membro da chamada "seita dos puritanos". Além da aprovação régia, era salutar certificar-se que o contrato matrimonial não causaria a antipatia do conde de Oeiras, declaradamente contrário aos "puritanos". Foi o que fez Lavradio, da Bahia, em 15 de dezembro de 1768:

Nesta ocasião me dá conta a Marquesa do ajuste do casamento de minha filha, combate comigo o gosto, e o susto, eu estimo esta aliança se ela for agradável a V.Ex. ${ }^{a}$ porque nessa certeza a tenho também da aprovação de Sua Majestade; eu não sei se nesta ocasião se fez quanto eu deixei recomendado, porque as únicas providências que deixei para a minha Casa, foram as apertadíssimas ordens, para que assim do destino dos meus filhos como de todos os mais interesses da minha família em que eu pudesse representar, se não desse um só passo que não fosse primeiro aprovado por V.Ex. ${ }^{a}$... V.Ex. ${ }^{a}$ é quem há de tomar debaixo dos seus auspícios a mim, a minha Casa, os meus filhos, e só me julgarei feliz quando tiver a certeza que tudo quanto me pertence, se conduz debaixo dos do- 
cumentos de V.Ex. ${ }^{a}$. O Conde de Vilar Maior, e seu filho me escreve[m] eu lhe[s] respondo remetendo as cartas com[o] esta também, à Marquesa do Lavradio,

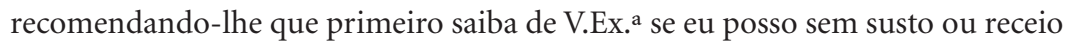
de ser menos agradável a Sua Majestade convir neste contrato, porque nesse caso não devo deixar de agradecer àqueles fidalgos, a estimabilíssima contemplação que tiveram com a minha Casa.... ${ }^{40}$

Os escrúpulos do marquês do Lavradio devem ser analisados a partir de uma medida do conde de Oeiras, contida no alvará de 5 de outubro de 1768, tornado público cerca de dois meses antes da referida correspondência entre o marquês e o Secretário de Estado. O alvará desferia um golpe na "seita dos puritanos", que congregava representantes de antigas Casas fidalgas. ${ }^{41} \mathrm{~A}$ existência oficial do "puritanismo" estava consignada no Compromisso da Confraria do Santíssimo Sacramento de Santa Engrácia, de 1663, que apontava as distinções adotadas pelos "puritanos” para excluir de suas alianças as Casas suspeitas de "contaminação" por sangue judeu, árabe ou negro. No bojo das medidas para promover os investimentos em Portugal e modificar certos códigos de comportamento da antiga nobreza, incompatíveis com a modernização pretendida por Pombal, estava o fim da distinção entre cristãos-velhos e cristãos-novos, incidindo sobre o "puritanismo". Porém, Francisco Falcon discute os limites ideológicos da medida contra os "puritanos", atribuindo-a mais a um ato político, um meio de golpear a fidalguia, que ao reconhecimento moral da indistinção entre cristãos-velhos e cristãos-novos. ${ }^{42}$

Por determinação do alvará, as famílias puritanas com filhos em condições de casar tinham um prazo de quatro meses para o ajuste dos casamentos com membros de famílias alijadas de seus círculos de aliados. Fora prescrito que a letra da Lei seria levada, individualmente, ao conhecimento dos fidalgos identificados com a "seita". Assim, foram chamados à presença do conde de Oeiras para a leitura do alvará, entre outros fidalgos, o conde de Vilar Maior, sogro de D. Maria Rosa de Almeida. ${ }^{43}$

Entre as Casas alijadas do círculo dos "puritanos", a de Lavradio foi a que mais concedeu filhas em matrimônio com os sucessores dos que se intitulavam "limpos de sangue". ${ }^{44} \mathrm{Na}$ carta de 15 de dezembro de 1768, fica claro que o conde de Vilar Maior realmente cumpriu o prazo estipulado pelo alvará para agenciar o casamento de seu filho. Quanto mais pela suspeita bastante curiosa contida na correspondência, acerca das possíveis relações entre Lavradio e o conde de Oeiras envolvendo D. Maria Rosa: "Esta filha devo dizer a V.Ex..$^{\underline{a}}$ que me deve todo o amor, ela mereceu sempre a V.Ex..$^{\underline{a}}$, desde os seus 
primeiros anos, muito carinho e favor, desejo não seja infeliz, suplico a V.Ex. ${ }^{\underline{a}}$ por ela a sua piedade e a sua proteção". ${ }^{45}$

É necessária cautela para afirmar sem nenhuma dúvida que o marquês do Lavradio e Sebastião José de Carvalho e Melo contraíram relações de "compadrio", embora fosse costume dos nobres, para ampliar seu círculo de relações na Corte, recomendar os filhos à proteção de indivíduos de reconhecida projeção, ou mesmo ao Rei. Referências a um possível "compadrio" entre as duas famílias aparecem em outras passagens da correspondência de Lavradio:

Meu Compadre, Meu Protetor, e Sr. do meu maior respeito ... a generosa piedade, com que V.Ex. ${ }^{\underline{a}}$ me favorece, e ampara, não permitem, que eu deixe de aparecer na presença de V.Ex. ${ }^{a}$ no meu particular como Marquês do Lavradio, a quem V.Ex. - tanto honra e favorece ... e deste modo fácil será que todos venham no reconhecimento, de que tudo devo à sábia, e generosa mão de V.Ex. ‥ Ela me subiu a este Lugar, para favorecer-me, suprimindo a minha inabilidade... ${ }^{46}$

Outro sinal de "compadrio" aparece em uma carta endereçada à marquesa de Pombal, na qual Lavradio relembrou o afeto que a família de Pombal nutria por D. Maria Rosa: "Beijo reverentemente os pés a V.Ex. ${ }^{\text {a }}$, pelas notícias que V.Ex..$^{a}$ se digna dar-me das minhas filhas: Eu não sei se elas vivem com V.Ex. ${ }^{a}$ tanto quanto eu desejo, e lhes recomendo, principalmente a minha Maria, que a V.Ex. ․ foi sempre tão obrigada". ${ }^{7}$

Acertados todos os passos para o consórcio, D. Maria Rosa de Almeida casou-se com Fernando Teles da Silva Caminha e Meneses, $7^{\circ}$ conde de Tarouca, $6^{\circ}$ marquês de Alegrete e $3^{\circ}$ marquês de Penalva, gentil-homem da Câmara de D. Maria I, censor da Mesa do Desembargo do Paço, deputado da Junta dos Três Estados e da Junta do Tabaco, sócio honorário da Academia Real das Ciências de Lisboa e tenente-general do Exército. Na administração ultramarina, governou as capitanias de São Paulo e do Rio Grande de São Pedro do Sul. Viúvo de D. Maria Rosa, Fernando Teles casou-se com a cunhada, D. Joana de Almeida. ${ }^{48}$

Para estreitar os laços de amizade com os membros da família de Sebastião de Carvalho e Melo, declarados como seus protetores na Corte, o marquês do Lavradio tratou de demonstrar total adesão à medida contra os "puritanos”. Na carta endereçada a Paulo de Carvalho, irmão de Sebastião José, em $1^{\circ}$ de maio de 1769 , concluídos os trâmites dos casamentos das primeiras filhas, Lavradio manifestou o desejo de que seus filhos mais novos ficassem sob a proteção do prelado: 
Agradeço-te os parabéns dos casamentos das duas raparigas, estas notícias me fizeram cá uma bulha muito grande, porque segundo o sistema daqueles senhores, certamente tão injurioso a toda a nobreza não podia esperar que se quisessem vir misturar com as nossas impuridades, o que te posso segurar é, que se eles guardavam sistema para si, a respeito de se não misturarem conosco, também eu para mim o tinha determinado para meu filho em observar o mesmo sistema a respeito deles; agora, porém para tudo deveremos ao nosso Augustíssimo Amo, e ao seu respeitável Ministério, cheio de grande consolação vemos extintas, e acabadas estas abomináveis seitas; agora Senhor Paulo entrego a você os meus dous filhos novos, e espero pela amizade que te devo, que tomando-os debaixo da tua proteção lhe $[s]$ hajas de lhe[s] dizer sempre o que entenderes para os seus acertos... ${ }^{49}$

Em 1774, Lavradio contratou o casamento da filha D. Ana Maria de Almeida com D. Francisco de Meneses, de família de reconhecida nobreza pelos senhorios, e o exercício de funções camarárias, mas sem titulação. $\mathrm{O}$ acerto do matrimônio reiterou as deferências mantidas com o marquês de Pombal:

A Marquesa do Lavradio me avisa em carta de 23 de dezembro do ano passado achar-se ajustada a casar minha filha dona Ana de Almeida com D. Francisco de Menezes. Diz-me a Marquesa, não ter dado neste negócio um só passo, sem o consentimento e aprovação de V.Ex. ${ }^{a}$ : por esta razão se multiplicam os motivos do grande contentamento com que recebo esta notícia: o primeiro ter sido V.Ex. ${ }^{a}$ quem dirigisse esta ação não querendo eu que na minha Casa haja nenhuma que não seja toda conduzida pelo conselho e vontade de V.Ex. ${ }^{a}$ e em segundo lugar por se multiplicarem à minha família, e aos meus netos a aliança com a Casa de V.Ex. ${ }^{a}$, que para mim é e será sempre de maior respeito, e estimação a qual deverão conservar eternamente os meus descendentes, em cujos corações e memórias será sempre permanente a lembrança dos incomparáveis benefícios que todos nós temos recebido, pela proteção, e amparo de V.Ex. a , e espero em Deus que nunca a vil e infame ingratidão, tenha forças para os fazer menos reconhecidos. Se algum tiver a desgraça de o ser, ele voltando-se para todos os Lados, que o nutrem, que o sustentam e que o puseram no estado feliz, reconhecendo sempre que a generosa mão de V.Ex. ${ }^{a}$ deve toda a sua felicidade, a confusão, e a vergonha, será o castigo mais tormentoso que o reduza a maior desesperação, próprio prêmio da sua infame culpa... ${ }^{50}$

D. Francisco de Meneses era filho de D. José de Meneses e Távora da Silveira e Castro, gentil-homem das Câmaras de D. José I e de D. Maria I, senhor 
dos morgados de Caparica e Patameira e comendador da Ordem de Cristo, casado com a condessa de Rapach, D. Luísa Gonzaga de Rapach, de origem austríaca. Os casamentos dos filhos de D. José de Meneses evidenciam uma atitude da nobreza não titulada de se unir a elementos da alta nobreza para aumentar seu prestígio e status social. Além de promover o enlace de D. Francisco com uma das filhas do marquês do Lavradio, D. José de Meneses acertou o casamento de outra filha, D. Maria Bárbara de Meneses, com D. Fernando José Lobo da Silveira Quaresma, $5^{\circ}$ conde de Oriola, $12^{\circ}$ barão, $1^{\circ}$ conde e $2^{\circ}$ marquês de Alvito, de cuja união, a segunda de D. Fernando, proveio a sucessão da Casa de Alvito. ${ }^{51}$

O casamento do herdeiro de Lavradio, D. Antônio Máximo de Almeida Portugal Soares Alarcão Melo Ataíde de Eça Mascarenhas Silva e Lancastre, reafirmou a aliança com a Casa de Alegrete e de Penalva. O futuro $3^{\circ}$ marquês do Lavradio casou-se em 1783 com D. Ana Teles da Silva, cunhada de sua irmã mais velha, D. Maria Rosa. D. Antônio Máximo foi vedor e estribeiro-mor da princesa D. Maria Benedita e mordomo-mor do príncipe D. João. Na administração do Reino, foi deputado da Junta dos Três Estados e, nas Armas, alcançou a patente de tenente-coronel de infantaria. ${ }^{52}$

Guardadas as devidas proporções e especificidades, o esquema de "compadrio" tinha finalidade muito semelhante à do casamento: estreitar relações, capitalizar ganhos políticos, reafirmar antigos laços de amizade, do tipo das "amizades" desiguais, que envolviam indivíduos de status social ou posição política distintos. ${ }^{53} \mathrm{O}$ "compadrio" se concretizava nas trocas de favores e na "proteção" e mantinha os elementos da nobreza, muito afeitos a estas práticas da sociabilidade de Antigo Regime, ainda mais aferrados aos deveres da honra. Afinal, o bom nome não era nutrido apenas com títulos, comendas e senhorios, mas também com a observância de princípios caros, como a "gratidão" e o "serviço". ${ }^{4}$

As relações de "compadrio" não se restringiam aos limites do Reino e da vida cortesã. Conscientes de seus valores e prerrogativas aristocráticas, os homens chamados ao Real Serviço no ultramar exercitavam e até mesmo reforçavam, atentos à distância que os separava do centro das decisões políticas, os laços de amizade e de fidelidade com seus pares e colaboradores. Com o marquês do Lavradio não sucedeu diferente. Na Bahia e no Rio de Janeiro, houve vários momentos em que exercitou a troca de favores e o compromisso de atender à recomendação de afilhados ou de facilitar a resolução de demandas pessoais de protegidos de parentes ou amigos. Exemplo disso está na carta endereçada ao conde de Povolide, em 14 de novembro de 1768, na qual Lavra- 
dio fez menção a um protegido do governador da Madeira, com quem também se correspondia: "o portador desta é um moço distinto das Ilhas que aqui chegou trazendo-me uma recomendação de D. Antão de Almada, ele pára a Pernambuco onde espero se faça merecedor da proteção de V.Ex. ${ }^{2}{ }^{\prime}{ }_{55}$

É possível inferir que a recomendação deveria abrir as portas do Real Serviço ao afilhado e protegido de D. Antão de Almada, sendo o moço encartado em alguma função administrativa, na tropa ou em algum tipo de comissão difícil de precisar, mas conforme as suas aptidões. Em outros casos, a procura por "proteção" visava à satisfação de demandas mais objetivas, como esclarece a carta de Lavradio ao governador de Minas, D. Antônio de Noronha, de quem era amigo de longa data, ${ }^{56}$ em 23 de outubro de 1775:

de Lisboa recebi uma carta a favor do Tenente Coronel Manuel Gomes Osório, assistente na Vila do Sabará, a fim de lhe favorecer as prontas cobranças do seu casal, que anda espelhado, cuja carta me põe na obrigação de rogar a V.Ex. ${ }^{a}$ a sua proteção para este homem em tudo o que o permitir a eqüidade e a justiça, ficando sempre prontíssimo para tudo o que for do gosto, e agrado de V.Ex.a. ${ }^{57}$

Deve-se notar que a recomendação e o pedido de "proteção" estavam assentados na promessa de retribuição, a manifestação antecipada da "gratidão", uma vez que o crédito do nome de Lavradio estava em jogo. De outro modo, era fundamental para o administrador colonial manter uma boa rede de interlocutores na Corte, capazes de sondar a repercussão dos seus feitos no ultramar. As informações colhidas funcionavam como termômetros do prestígio pessoal e familiar daquele que estava impossibilitado pela distância de agir em defesa própria. A preocupação em averiguar a receptividade de suas ações foi presença contumaz no cotidiano do marquês do Lavradio nos onze anos em que esteve na América. Em menos de um ano no governo da Bahia, já demonstrava a sua ansiedade pedindo ao amigo João Gomes de Araújo que colhesse impressões de sua gestão e da continuidade do favor que lhe dispensavam seus protetores, ao que tudo indica, encabeçados por Pombal:

A meus amigos e protetores escrevo dando conta do que tenho feito cheio da mais sincera ingenuidade, lhes peço a eles o socorro do seu conselho. V.me. que os ouve de mais perto do que a distância que eu lhes escrevo, lhes peço os queira instigar para que me queiram dar mais esta prova do seu favor, e de que mereço a sua proteção. ${ }^{58}$ 
A conjuntura do período pombalino, em que se estabeleceram tensões em torno dos privilégios da fidalguia, demonstra que esquemas de relacionamento rotineiros na sociedade de Antigo Regime continuavam a ter peso significativo no equilíbrio da balança do prestígio e da honra. A documentação da Casa de Lavradio não permite asseverar se houve o estabelecimento de um "compadrio" com a Casa de Pombal, por meio do batismo de D. Maria Rosa de Almeida. A falta dessa certeza talvez não signifique grande prejuízo, uma vez que o contexto político e a luta pela sobrevivência da linhagem indicam que era mais útil que o afilhado e protegido de Pombal fosse mesmo o marquês do Lavradio.

\section{COMPROMISSO COM A HONRA PESSOAL E DA CASA}

O marquês do Lavradio não precisava manter a deferência a Pombal e sua família simplesmente pelo medo da perseguição, mas para permanecer no Real Serviço e, conseqüentemente, resguardar o prestígio e a honradez de sua Casa. A Casa de Lavradio enfrentava dificuldades financeiras desde que o $1^{\circ}$ marquês, D. Antônio, retornou do governo de Angola, tendo se agravado pelas próprias demandas do Real Serviço, quando foi indicado para um posto militar em Elvas e para vice-rei do Estado do Brasil. O próprio $2^{\underline{ }}$ marquês do Lavradio precisou dispor de recursos para participar da Campanha Peninsular de 1762 e assumir o governo da Bahia, em 1768. Pouco tempo antes de vir para a Bahia, os embaraços pecuniários levaram a que o marquês pretendesse se afastar da Corte, recolhendo-se constrangido à Quinta da Conceição. Além disso, os casamentos das primeiras filhas também contribuíram para onerar as despesas da Casa.

Em 20 de fevereiro de 1770, pouco tempo depois de assumir o vice-reinado, Lavradio queixou-se ao Principal Almeida das dificuldades enfrentadas por seus antecessores e experimentadas por ele, para sustentar com dignidade a posição de representante máximo do Rei na colônia, sem prejudicar o seu cabedal particular:

tem este Governo para cima de cinco mil cruzados a menos de rendimento que o que eu deixei, custam os gêneros justamente dobrados do que na Bahia, são as ocasiões de despesas muito mais repetidas porque aqui é a passagem geral de todos os Governadores e Ministros que vêm à América, é finalmente um Governo tão útil que o Senhor Conde da Cunha mandando vir todos os anos a maior parte do ren- 
dimento da sua Casa não tendo dado nunca um jantar público ficou devendo 16 mil cruzados, e o meu antecessor, que se não pode viver mais parcamente do que S.Ex. ${ }^{a}$ vivia, foi obrigado agora na sua retirada a vender até o último guardanapo, e garfo de que se servia, e um destes dias assinou uma escritura de dívida de dez mil, para poder ter com que fizesse a sua torna-viagem; ora colija V.Ex. ${ }^{a}$ agora daqui em que estado ficarei eu se Sua Majestade não der providência a que os Vicereis tenham o soldo competente, pois para o servirmos com independência o não podemos fazer totalmente sem arruinarmos as nossas Casas... ${ }^{59}$

Para tentar sanar os problemas financeiros, o marquês do Lavradio intercedeu junto a José de Seabra da Silva, a quem expôs os riscos que corriam a honra de seu nome e a segurança de sua descendência, caso os empenhos não fossem saldados. A primeira carta a Seabra da Silva foi enviada em 30 de janeiro de 1772:

Agradeço a V.Ex. ${ }^{a}$ o ter-se querido encarregar de patrocinar a minha Casa como a Marquesa mo segura, ela a bem necessita de um socorro superior, para eu poder ter com que possa habilitar meu filho para entrar no serviço de El-Rei meu Senhor, e poder servi-lo, e a sua Pátria como eu desejo, eu nessa parte principio a descansar se a proteção de V.Ex. ํㅗ se juntar ao favor com que o Senhor Marquês de Pombal tanto me tem até agora protegido e amparado... ${ }^{60}$

A segunda carta foi escrita no mês seguinte e dá mais detalhes das vexações e desordens da Casa de Lavradio. No Rio de Janeiro, Lavradio encontrou uma solução para saldar as dívidas, e comunicou-a a José de Seabra da Silva, na tentativa de que a sua interseção, aliada à proteção do marquês de Pombal, salvasse a sua Casa da ruína financeira:

Se Sua Majestade ... em atenção ao grande desejo que tenho de o servir com acerto, fosse servido dar-me uma fazenda que os [denominados] jesuítas possuíam a uma légua distante desta Capital, chamado o Engenho Novo ... poderia desta forma suprir os grandíssimos prejuízos que tenho tido e ver mais facilmente a minha Casa em estado de eu poder respirar ... A generosidade com que Sua majestade tem com algumas fazendas desta qualidade favorecido a muitos dos seus vassalos, me anima a este requerimento, e me esperanceia com a proteção de V.Ex. ${ }^{\underline{a}}$ e do Senhor Marquês de Pombal, eu poderei ser felizmente deferido... ${ }^{61}$ 
As dificuldades financeiras eram comuns a muitas Casas, independentemente do status nobiliárquico, e a administração ultramarina, em certos casos, não foi simplesmente um meio de obter prebendas da Coroa para acrescentar ao patrimônio da família. Alguns anos antes do marquês do Lavradio, Luís Diogo Lobo da Silva, governador de Pernambuco e de Minas Gerais, encontrou na administração ultramarina a oportunidade para reabilitar o nome de seus antepassados, recuperando a honra de sua Casa, e uma alternativa para salvá-la do descalabro financeiro por meio das mercês recebidas pelos serviços prestados à Coroa. ${ }^{62}$

A preocupação constante dos administradores coloniais com a boa recepção de suas ações de governo na Corte estava diretamente relacionada à manifestação da benemerência régia. Acusações de desmandos, desobediências, improbidades e intrigas recaíam com certa freqüência sobre os governantes, comprometendo não só a sua honra, mas a obtenção de mercês pelos serviços prestados no ultramar. A correspondência privada do marquês do Lavradio contém diversas passagens nas quais o vice-rei indaga a seus interlocutores sobre a existência, na Corte, de rumores positivos ou negativos a respeito de sua administração, como transparece em uma carta à marquesa de Pombal:

Permita-me V.Ex. ${ }^{\underline{a}}$ minha Senhora, que eu ainda me lembre, e me doa da falsidade, e injustiça com que não sei quem, nem porque motivo me criminaram na presença de V.Ex. ․ . Esta chaga é sempre viva no meu coração, aquele coração, que nunca foi ingrato, nem o será, àqueles a quem é tão obrigado como eu, que com a voz mai[s] alta, e forte publicarei sempre o quanto estou à Casa de Oeiras, distinguindo-me sempre V.Ex. ${ }^{-}$com tanta especialidade, desde o primeiro dia, que tive a honra de me apresentar aos seus pés... ${ }^{63}$

A tradição de serviços da Casa de Lavradio foi versejada nos Venturosos Anúncios na Chegada do Ilmo. e Exmo. Sr. Marquês do Lavradio... à Cidade do Rio de Janeiro por Vice-rei e Capitão-general de Mar e Terra do Estado do Brasil, proclamados em 1770 . O cronista realçou as virtudes políticas do novo vice-rei como atributos das Grandes Casas nobiliárquicas de Portugal:

Com as rédeas do teu vastíssimo Governo têm premiado os passados Monarcas os mais relevantes serviços: com elas honrou os Sás, os Henriques, os Pereiras, Lobos e Mendonças; os Lancastros, os Meneses, Mascarenhas, e Albuquerques, os Saldanhas, Andrades, Cunhas, e Rolins ... por isso mesmo tantas vezes 
laureados em todas as quatro partes do mundo com os governos das mais importantes praças, dos mais opulentos estados: uns com os respeitáveis títulos de Condes de Avintes, e Marqueses do Lavradio; outros com os de Condes de Assumar e Marqueses de Alorna; e todos com as brilhantes alianças da mais preclara Nobreza... ${ }^{64}$

Os Venturosos Anúncios... cantam os feitos da família Almeida por meio de versos que destacam a amplitude dos seus serviços, a importância das alianças e o valor do favorecimento real:

$\cdots$

Porque, eterna nos fastos da Memória;

Inunde o mundo todo a nossa glória;

Os sonoros clarins afina; e conta

Dos Almeidas os feitos majestosos;

De que foi teatro ilustre Goa, e Diu,

Damão, Tânger, Mazagão, Sofala,

Moçambique, Salcedo, e praça d'Elvas.

As augustas alianças, que tiveram,

Dos Nacionais respeitos, dos estranhos;

E do especial apreço, que os Monarcas

Sempre de Almeidas, e Almeidões fizeram

${ }^{65}$

\section{A REMUNERAÇÃO DOS SERVIÇOS - CONSIDERAÇÕES FINAIS}

A imagem da administração do marquês do Lavradio se consolidou na historiografia como o resultado bem acabado da política colonial idealizada no período pombalino. ${ }^{66}$ As experiências militares e os valores nobiliárquicos permitiram que o governador e vice-rei conseguisse equilibrar as vicissitudes da governança, com os códigos de comportamento e as posturas da fidalguia, diante do crivo de seus pares na Corte. Uma análise de sua correspondência pessoal, as conhecidas Cartas da Bahia e Cartas do Rio de Janeiro, excederia os limites deste trabalho, mas permite a verificação desse arranjo em prol da honra e da sobrevivência política da Casa de Lavradio.

Outro traço da imagem de Lavradio que se consolidou é o de um admi- 
nistrador desinteressado, que não se valeu das posições em que esteve para obter vantagens pecuniárias. ${ }^{67}$ De seu biógrafo e descendente, de quem é possível esperar exageros, ficou a notícia de que o vice-rei, de retorno a Portugal, não dispunha sequer de uma moeda para gratificar os remadores do escaler que o conduziu a terra, assim como adquiriu, às expensas do filho que providencialmente lhe forneceu os meios, jóias para as filhas fingindo tê-las trazido do Rio de Janeiro. ${ }^{68}$ Contudo, a penúria material, não importa em que monta, vinha acompanhada da limpeza do nome.

O caráter absolutista da ação de Pombal pode ter levado ao afastamento de alguns círculos tradicionais da nobreza da esfera das decisões políticas. ${ }^{69}$ Porém, estava no centro da perspectiva de mediação, em lugar da generalizada e irreversível aversão entre o pombalismo e a velha nobreza, a defesa que a fidalguia empreendeu de seus privilégios e da primazia no Real Serviço. Nesse caso, não se considera aquele grupo identificado como entraves à política pombalina, mas os fidalgos que preferiram manter-se próximos de Pombal para não perder de todo os ganhos políticos. Afinal, a Coroa não podia prescindir dos préstimos de indivíduos desejosos de bem servir à pátria, ainda que para aumentar os seus cabedais. Exemplo disso foi a Casa de Lavradio, pois, regra geral, o prêmio para aqueles que provinham da fidalguia e serviram no ultramar era mais uma comenda ou título acrescentado ao patrimônio da Casa, no caso de terem sido administradores reconhecidamente probos. ${ }^{70}$

$\mathrm{Na}$ memória dos que governou, o marquês do Lavradio deixou a impressão favorável que de costume se registrava nos elogios e orações fúnebres dos governantes, como a proferida por Frei Antônio de Santa Úrsula Rodovalho nas exéquias do vice-rei, em 1790:

sem perder de vista o elevado berço, em que nasceram, e a dura obrigação de imitar os seus antepassados, no meio das honras, e dos mais altos empregos souberam adquirir um nome imortal, desmente de uma vez o cego sistema de seus adversários, e faz aparecer, quando ela estima o bom Cidadão, o bom Vassalo, o Amigo da pátria, o Benfeitor da Nação, o Conservador dos Povos; o homem enfim, que soube fazer-se a alegria, a esperança, a consolação dos outros homens ... Os portugueses devem reconhecer na linha dos Almeidas uma dádiva singular, e um benefício permanente, que lhes tem concedido a Providência. Suscitados por Deus para dirigir por suas mãos a salvação dos Povos, eles são os que nas diversas situações da Monarquia ... de uma glória que apesar de África, e de Ásia, mas com honra de Europa, e com gosto particular da América, conserva em todas estas partes vestígios indeléveis... ${ }^{71}$ 
De volta a Portugal, depois de onze anos de serviços, Lavradio foi recompensado com o governo militar da Torre de São Julião da Barra, os cargos de conselheiro da Guerra, de presidente do Desembargo do Paço, de inspetorgeral das tropas do Alentejo e Algarve e de vedor da rainha D. Maria I, e com a Grã-cruz da Ordem de Cristo. Isso comprova que, independentemente das vicissitudes políticas, a fidalguia estava preocupada em manter as antigas prerrogativas consolidadas pela tradição social e política do Antigo Regime. As mercês eram a manifestação do vigor de uma fórmula política muito cara à fidalguia, enunciada na epígrafe do elogio fúnebre ao marquês do Lavradio: "Curam habe de bono nomine: hoc enim magis permanebit, quam mille thesauri pretiosi, e magni (Cuida de um bom nome: porque ele te será mais permanente do que mil tesouros preciosos, e grandes)" ${ }^{72}$ O nome era, sem dúvida, o patrimônio mais valioso de um fidalgo.

\section{NOTAS}

${ }^{1}$ Doutorando em História Social na Universidade de São Paulo, sob a orientação da Profa. Dra. Maria Beatriz Nizza da Silva. Este artigo é baseado na dissertação de mestrado defendida em abril de 2002, no Programa de Pós-graduação em História Política da Universidade do Estado do Rio de Janeiro, orientada pela Profa. Dra. Lúcia Maria Bastos Pereira das Neves. O trabalho contou com o apoio da Fundação de Amparo à Pesquisa do Estado do Rio de Janeiro - Faperj.

${ }^{2}$ GOUVÊA, M. de F. S. Poder Político e Administração na Formação do Complexo Atlântico Português (1645-1808). In: FRAGOSO, J. L. R.; BICALHO, M. F. B. e GOUVÊA, M. de F. S. (Org.) O Antigo Regime nos Trópicos: a dinâmica imperial portuguesa (séculos XVIXVIII). Rio de Janeiro: Civilização Brasileira, 2001, p.287.

${ }^{3}$ Sobre a trajetória administrativa do marquês do Lavradio, há o conhecido trabalho de ALDEN, D. Royal Government in Colonial Brazil: with special reference to the administration of the Marquis of Lavradio, viceroy, 1769-1779. Berkeley: University of California Press, 1968. Sobre o Morgado de Mateus, há o livro de BELLOTTO, H. L. Autoridade e Conflito no Brasil Colonial: o governo do Morgado de Mateus em São Paulo (1765-1775). São Paulo: Secretaria de Estado da Cultura, Conselho Nacional de Artes e Ciências Humanas, 1979. Para as abordagens recentes acerca das relações que governadores e vice-reis mantinham com as instâncias administrativas coloniais e com seus pares e interlocutores na Corte, refiro-me aos estudos de SOUZA, L. de M. e. Os Nobres Governadores de Minas. Mitologias e Histórias Familiares. In: . Norma e Conflito: Aspectos da História de Minas no Século XVIII. Belo Horizonte: UFMG, 1999, p.175-99; e Administração Colonial e Promoção So- 
cial: a atividade de Luís Diogo Lobo da Silva como governador e capitão-general de Pernambuco e Minas Gerais. In: SILVA, M. B. N. da. (Coord.) De Cabral a Pedro I: aspectos da colonização portuguesa no Brasil. Porto: Universidade Portucalense, 2001, p.277-87. Sobre os critérios de recrutamento e desempenho dos governos ultramarinos, ver: MONTEIRO, N. G. F. Trajetórias Sociais e Governo das Conquistas: notas preliminares sobre os vice-reis e governadores-gerais do Brasil e da Índia nos séculos XVII e XVIII. In: FRAGOSO, J. L. R.; BICALHO, M. F. B. e GOUVÊA, M. de F. S. (Org.), op. cit., p.249-83.

${ }^{4}$ Cf. SÉRGIO, A. et al. (Dir.) GRANDE ENCICLOPÉDIA PORTUGUESA E BRASILEIRA, v.3. Lisboa, Rio de Janeiro: Editorial Enciclopédia, s.d., p.67.

${ }^{5}$ Para todas as referências biográficas do $2^{\circ}$ marquês do Lavradio, ver: José d'Almeida Correia de Sá. Vice-reinado de D. Luiz d'Almeida Portugal, $2^{\circ}$ Marquês do Lavradio, $3^{\circ}$ Vice-rei do Brasil. São Paulo: Ed. Nacional, 1942 e ZUQÜETE, A. E. M. (Dir.) Nobreza de Portugal e do Brasil. Lisboa, Rio de Janeiro: Editorial Enciclopédia, 1989, v.3, p.291-2. Ver também os verbetes sobre o marquês do Lavradio, de BELLOTTO, H. L. In: SILVA, M. B. N. da. (Coord.) DICIONÁRIO DA HISTÓRIA DA COLONIZAÇÃO PORTUGUESA NO BRASIL. Lisboa: Verbo, 1994; e de GOUVÊA, M. de F. S. In: VAINFAS, R. (Dir.) DICIONÁRIO DO BRASIL COLONIAL, 1500-1808. Rio de Janeiro: Objetiva, 2000.

${ }^{6}$ Ibidem, p.537.

${ }^{7}$ ZUQÜETE, A. E. M. (Dir.), op., cit., v.2, p.355.; SOUZA, L. de M. e. Os Nobres Governadores de Minas..., op. cit., p.175-6.

${ }^{8}$ Para informações mais detalhadas sobre as concepções linhagistas da fidalguia e seus meios de reprodução, ver: MONTEIRO, N. G. O Crepúsculo dos Grandes: a casa e o patrimônio da aristocracia em Portugal (1750-1832). Lisboa: Imprensa Nacional/Casa da Moeda, 1998.

${ }^{9}$ Ibidem, p. 150 .

${ }^{10}$ MONTEIRO, N. G. O Crepúsculo dos Grandes..., p.540.

${ }^{11}$ SUBTIL, J. Os Poderes do Centro. In: HESPANHA, A. M. (Coord.) História de Portugal: o Antigo Regime (1620-1807). Lisboa: Estampa, 1998, v.4, p.162.

${ }^{12}$ Cf. GOUVÊA, M. de F. S. Poder, Justiça e Soberania no Império Colonial Português (17501822). Leituras: Revista da Biblioteca Nacional. Lisboa, S.3, n.6, abr.-out.2000, p.107-9.

${ }^{13}$ MONTEIRO, N. G. O Crepúsculo dos Grandes..., p.537 e 539.

${ }^{14}$ Ibidem, p.536-7.

${ }^{15}$ SÁ, J. d'A. C. de., op. cit., p.5.

${ }^{16}$ ALDEN, D., op. cit., p.3-4. 
${ }^{17}$ Para uma análise mais aprofundada dos conceitos de "campo", "trajetória", "história de vida" e "agente eficiente”, ver: BOURDIEU, P. A Ilusão Biográfica. In: FERREIRA, M. de M., AMADO, J. (Org.) Usos \& Abusos da História Oral. 2.ed. Rio de Janeiro: Ed. FGV, 1996, p.183-91.

${ }^{18}$ MONTEIRO, N. G. F. O "Ethos" da Aristocracia Portuguesa sob a Dinastia de Bragança: Algumas Notas sobre a Casa e o Serviço ao Rei. Revista de História das Idéias. Coimbra: Artipol, v.19, 1998, p.383-402.

${ }^{19}$ Ibidem, p.384-5.

${ }^{20}$ XAVIER, Â. B., HESPANHA, A. M. As Redes Clientelares. In: HESPANHA, A. M. (Coord.) História de Portugal. O Antigo Regime (1620-1807). Lisboa: Estampa, 1998, v.4, p.339-49.

${ }^{21}$ SOARES, S. C. Nobreza e Arquétipo Fidalgo: a propósito de um Livro de Matrícula de Filhamentos (1641-1724). Revista de História das Idéias. Coimbra: Artipol, v.19, 1998, p.405.

${ }^{22}$ Como indicação de um estudo dos mais recentes sobre o período pombalino, cito MAXWELL, K. Marquês de Pombal: Paradoxo do Iluminismo. Trad. Antônio de Pádua Danesi, 2.ed. Rio de Janeiro: Paz e Terra, 1997.

${ }^{23}$ AZEVEDO, J. L. de. O Marquês de Pombal e a Sua Época. 2.ed. Lisboa: Livraria Clássica, 1990.

${ }^{24}$ MARTINS, F. J. da R. O Marquês de Pombal Desterrado, 1777-1782. Lisboa: Empresa Nacional de Publicidade, 1939, p.96.

${ }^{25}$ AZEVEDO, J. L. de., op. cit., p.142-4.

${ }^{26}$ A menção de Kenneth Maxwell a D. Tomás de Almeida perpetua um problema de identificação da pessoa de D. Tomás de Almeida, primeiro Patriarca de Lisboa. Maxwell considera-o "irmão" do vice-rei, enquanto nas Cartas do Rio de Janeiro D. Tomás de Almeida aparece como "tio" de Lavradio, homônimo do tio-avô que presidiu seus estudos preliminares e que faleceu em 1754, não podendo sero mesmo D. Tomás que foi Diretor Geral dos Estudos, cargo criado após a expulsão dos jesuítas, em 1759.

${ }^{27}$ Ibidem, p.115-6.

${ }^{28}$ FALCON, F. J. C. A Época Pombalina (Política Econômica e Monarquia Ilustrada). 2.ed. São Paulo: Ática, 1993. O Reformismo Ilustrado engloba um conjunto de reformas implantadas no ministério de Pombal, visando, segundo uma interpretação clássica, à recuperação de Portugal do "atraso" ou defasagem política, cultural e econômica em relação às nações ditas "civilizadas" da Europa. As reformas que incidiram sobre os campos jurídico e religioso, determinaram a secularização da administração pública; no campo político, buscaram o reforço do poder régio e a dinamização da economia colonial, de cujo bom 
desempenho dependia a recuperação econômica de Portugal. De maneira ampla, pode-se dizer que Portugal estava inserido no "espírito das reformas" que invadiu a Europa das Luzes na segunda metade do século XVIII. Cf. VENTURI, F. Europe des Lumières - recherches sur le 18eme. siècle. Paris: Mouton, 1971, p.27. Para uma abordagem clássica do Reformismo Ilustrado, ver também: NOVAIS, F. A. O Reformismo Ilustrado Luso-Brasileiro: alguns aspectos. Revista Brasileira de História. São Paulo, v.4, n.7, 1984, p.105-18.

${ }^{29}$ Ibidem, p.377.

${ }^{30}$ Biblioteca Nacional de Lisboa (doravante BNL). Seção de Reservados. "Cantigas contra o Marquês de Pombal". Códice 10567 (69), s.n.

${ }^{31}$ MONTEIRO, N. G. Poder Senhorial, Estatuto Nobiliárquico e Aristocracia. In: HESPANHA, A. M. (Coord.) História de Portugal. O Antigo Regime (1620-1807). Lisboa: Estampa, 1998, v.4, p.297-338.

${ }^{32}$ BNL. Seção de Reservados. “Cantigas contra o Marquês de Pombal”. Códice 10567 (69), s.n.

${ }^{33}$ FALCON, F. J. C., op. cit., p.214 e 216.

${ }^{34}$ Cf. XAVIER, Â. B., HESPANHA, A, M., op. cit., p.339.

${ }^{35}$ Ibidem, p.340-3.

${ }^{36}$ SUBTIL, J. Os Poderes do Centro. In: HESPANHA, A. M. (Coord.) História de Portugal: O Antigo Regime (1620-1807). Lisboa: Estampa, 1998, v.4, p.159-61.

${ }^{37}$ Cf. SILVA, M. B. N. da. A Legislação Pombalina e a Estrutura da Família no Antigo Regime Português. In: SANTOS, M. H. C. dos. (Coord.) Pombal Revisitado, v.1. Lisboa: Estampa, 1984, p.403-14.

${ }^{38}$ SÉRGIO, A. et al. GRANDE ENCICLOPÉDIA..., op. cit., v.2, p.594.

${ }^{39}$ LAVRADIO, Marquês do. Cartas da Bahia (1768-1769). Rio de Janeiro: Arquivo Nacional, 1972, p.178-9.

${ }^{40}$ Ibidem, p.61-3.

${ }^{41}$ Para as considerações sobre o "puritanismo", ver também: AZEVEDO, J. L. de. História dos Cristãos-Novos Portugueses. Lisboa: Livraria Clássica, 1921, p.349-50.

${ }^{42}$ FALCON, F. J. C. A Época Pombalina..., p.400-1.

${ }^{43}$ No grupo dos fidalgos intimados para a leitura do alvará de 5 de outubro de 1768, João Lúcio de Azevedo incluiu, além do $6^{\circ}$ conde de Vilar Maior, o marquês de Valença, o marquês Monteiro-mor Francisco de Melo, Fernando Xavier de Miranda Henriques, conde de Sandomil e o $3^{\circ}$ marquês de Angeja. Este último era sogro de D. Teresa Francisca de Al- 
meida e não há indicações na correspondência do marquês do Lavradio de que o $3^{\circ}$ marquês de Angeja pertencesse à “seita dos puritanos”. AZEVEDO, J. L. de., op. cit., p.350.

${ }^{44}$ MONTEIRO, N. G. O Crepúsculo dos Grandes..., p.138.

${ }^{45}$ LAVRADIO, Marquês do. Cartas da Bahia..., op. cit., p.63.

${ }^{46}$ BNL. Seção de Reservados. Códice 10624, fls. 19-20. Grifos meus.

${ }^{47}$ LAVRADIO, Marquês do. Cartas do Rio de Janeiro (1769-1776)..., Rio de Janeiro: Secretaria de Estado de Educação e Cultura; Instituto Estadual do Livro, 1978, p.167.

${ }^{48}$ SÉRGIO, A. et al., op. cit., v.20, p.947-8.

${ }^{49}$ Ibidem, p.169-70.

${ }^{50}$ BNL. Seção de Reservados. Códice 10624, fl. 47v.

${ }^{51}$ ZÜQUETE, A. E. M. (Dir.), op. cit., v.2, p.269.

${ }^{52}$ SÉRGIO, A. et al., op. cit., v.14, p.762.

${ }^{53}$ XAVIER, Â. B., HESPANHA, A. M. As Redes Clientelares. In: HESPANHA, A. M. (Coord.) História de Portugal. O Antigo Regime (1620-1807). Lisboa: Estampa, 1998, v.4, p.339.

${ }^{54}$ Ibidem, p.342.

${ }^{55}$ LAVRADIO, Marquês do. Cartas da Bahia..., op. cit., p.59.

${ }^{56}$ LAVRADIO, Marquês do. Cartas do Rio de Janeiro (1769-1776)..., op. cit., p.160. Na carta a D. Antônio de Noronha, de 16 de agosto de 1775, Lavradio fez alusão à amizade antiga entre os dois, dizendo "que o meu Antônio de Lisboa me não deve mais amor, e interesse que o meu Antônio de Vila Rica...”.

${ }^{57}$ LAVRADIO, Marquês do. Cartas do Rio de Janeiro (1769-1776)..., op. cit., p.162.

${ }^{58}$ Ibidem, p.90.

${ }^{59}$ LAVRADIO, Marquês do. Cartas do Rio de Janeiro (1769-1776)..., op. cit., p.16.

${ }^{60}$ Ibidem, p.93.

${ }^{61}$ Ibidem, p.94-5.

${ }^{62}$ SOUZA, L. de M. e. Administração Colonial e Promoção Social..., op. cit., p.284.

${ }^{63}$ LAVRADIO, Marquês do. Cartas do Rio de Janeiro (1769-1776)..., op. cit., p.167.

${ }^{64}$ BNL. Sala de Leitura Geral. SOUZA, F. J. de. Venturosos Anúncios na Chegada do Ilmo. e Exmo. Sr. Marquês do Lavradio... à cidade do Rio de Janeiro por Vice-rei e Capitão-general de Mar e Terra do Estado do Brasil. Lisboa: Oficina de Miguel Rodrigues, 1771, 29p.

${ }^{65}$ Ibidem, s.n. 
${ }^{66}$ GOUVÊA, M. de F. S. Poder Político e Administração na Formação do Complexo Atlântico Português (1645-1808), op. cit., p.307.

${ }^{67}$ Ibidem, p.278.

${ }^{68}$ SÁ, J. d'A. C. de. Vice-reinado de D. Luiz d'Almeida Portugal..., p.2.

${ }^{69}$ No que diz respeito à relação da política pombalina com a fidalguia pode-se dizer, de acordo com a interpretação de Nuno Gonçalo Monteiro, que se por um lado Pombal não alterou significativamente os mecanismos de reprodução social das Casas nobiliárquicas, procurando mesmo garanti-los, por outro lado submeteu-as totalmente aos desígnios do Rei. Mesmo após a queda de Pombal, a fidalguia não mais recuperou a forte presença que tinha nos espaços de decisão política da monarquia. Cf. MONTEIRO, N. G. Poder Senhorial, Estatuto Nobiliárquico e Aristocracia. In: HESPANHA, A. M. (Coord.) História de Portugal. O Antigo Regime (1620-1807). Lisboa: Estampa, 1998, v.4, p.303.

${ }^{70}$ MONTEIRO, N. G. Trajetórias Sociais e Governo das Conquistas: notas preliminares sobre os governadores-gerais e vice-reis do Brasil e da Índia nos séculos XVII e XVIII, op. cit., p.275-9.

${ }^{71}$ BNL. Seção de Reservados. RODOVALHO, Frei A. de Santa Úrsula. Oração Fúnebre, à Memória do ... Marquês do Lavradio, recitada na Catedral do Rio de Janeiro, nas exéquias, que lhe consagraram os cidadãos da mesma Cidade pelo R. P. M.... Lisboa: [s.n.t], 1790, p.1. ${ }^{72}$ Ibidem, p.1 e p.5-6. 